\title{
Hibridisasi budaya: studi kasus dua drama korea tahun 2018-2020
}

\author{
Dyah Ayu Wiwid Sintowoko \\ Telkom University
}

\begin{abstract}
ABSTRAK
Kajian tentang hibridisasi budaya Korea dalam konten drama masih diperdebatkan hingga sekarang oleh beberapa peneliti terdahulu. Penelitian ini bertujuan untuk mengetahui bentuk hibridisasi budaya Korea melalui drama The World of the Married dan Touch Your Heart dengan pendekatan teori visual lavish production. Penelitian ini menggunakan metode kualitatif dan teori lavish production untuk menemukan kesan mewah pada visual drama Korea. Karakteristik lavish production pada visual drama juga dianalisis melalui mise-en-scene untuk mengidentifikasi hibridisasi budaya Korea. Hibridisasi budaya dan kesan lavish production di dalam drama Korea tercermin melalui mise-en-ecene. Hibridisasi juga merupakan dampak dari diadaptasinya slogan Learning from Hollywood oleh sineas Korea. Adapun konsep drama trendy Korea merupakan adaptasi strategi dari Jepang untuk memunculkan kesan Asian taste. Hasil penelitian menunjukkan bahwa: (1) lavish production mengacu pada classy mise-en-scene dimana setting, properti, narasi dan gesture karakter sangat merepresentasikan perubahan teknis standar industri drama Korea menjadi cinematic orientation; (2) hibridisasi tampak pada kostum, gesture, dan beauty standart ala Western style yang didukung dengan narasi adaptasi trendy drama dari Jepang. Romantisme, non-sex dominant dan eyecontact merepresentasikan Asian sentiment karena cenderung menggunakan pendekatan estetika olah rasa; dan (3) konsep hibridisasi akan mengalami perkembangan bukan hanya di ranah budaya saja, namun juga pada produk budaya itu sendiri karena adanya persaingan global dan eksistensi Western media mainstream di Asia.
\end{abstract}

Kata-kata kunci: Asian taste; cinematic orientation; drama Korea; hibridisasi budaya; lavish production

\section{Cultural hybridization: a case study of two korean dramas between} \section{8-2020}

\begin{abstract}
The study on cultural hybridization of Korean drama has been debated by previous researchers until now. This research aims to determine the hybridization of Korean culture through dramas. The World of the Married and Touch Your Heart, with a lavish production visual approach. This study uses qualitative method to find a luxurious impression in the Korean drama visual. The characteristics of lavish production is analyzed through mise-en-scene to identify the hybridization of Korean culture as well. Cultural hybridization is an impact of adopting a slogan "Learning from Hollywood" by Korean filmmakers. Meanwhile, drama trendy concept has been adopted form Japan to expose the Asian taste impression. Results show that: (1) lavish production refers to a classy mise-en-scene where the setting, properties, narration and character's gesture represent technical changes in Korean industry standard to a cinematic orientation; (2) hybridization can be seen through costumes, gesture, and Western-style beauty standard that supported by a narrative adaptation of drama trendy from Japan. Romanticism, non-sex dominant and eye-contact represent Asian sentiment because of the aesthetic tendencies and emotional approach; and (3) hybridization concept will develop not only in cultural society but also in cultural product itself because of the global competition and Western media mainstream existence in Asia.
\end{abstract}

Keywords: Asian taste; cinematic orientation; cultural hybridization; Korean drama; lavish production

Korespondensi: Dyah Ayu Wiwid Sintowoko, S.Sn., M.A. Fakultas Industri Kreatif, Telkom University. Jln. Telekomunikasi No.1-Sukapura, Dayeuhkolot, Bandung, 40257.Email: dyahayuws@telkomuniversity.ac.id 


\section{PENDAHULUAN}

Drama Korea saat ini telah menggeser western media mainstream. Kemungkinan besar alasannya adalah karena adanya fenomena Korean Wave atau hallyu, yang secara bertahap namunmassivetelahmendorongberkembangnya budaya popular Korea. Salah satu contoh produk Korea adalah drama yang mengandung budaya populer Korea sekaligus sebagai sebuah contoh produk cultural hybridization (Lee dkk., 2020). Cultural hybridization atau hibridisasi budaya ini menyoroti bagaimana suatu negara telah mengalami sesuatu yang tidak bisa terhindarkan oleh pemikiran postmodern. Postmodern sangat menjunjung tinggi pemikiran-pemikiran yang konstruktif di hampir seluruh lapisan ilmu pengetahuan termasuk teknologi, socialscience, agama dan seni (Iyorza \& Ekwok, 2014). Era postmodern mengantarkan seseorang pada pemikiran-pemikiran yang lebih "liar" dan cenderung tidak mau dibatasi pada aturan-aturan yang "mengekang" kebebasan dan kreativitas. Salah satu implikasi yang sangat terlihat pada era abad ke-20 ini adalah hibridisasi atau perkawinan dalam budaya. Postmodern tampak menghalalkan adanya gebrakan enkulturasi dan akulturasi terhadap gerakan adopsi budaya asing pada hibridisasi budaya ini. Oleh sebab itulah, hybrid culture tidak lain memiliki sebutan baru yaitu "spesies budaya" yang mengandung hasil racikan globalisasi sebagai ramuan mixed cultures.

A mixed culture adalah hasil olahan budaya multi national karena globalisasi. Praktik mengadopsi budaya asing dilakukan sesuai dengan kepentingan dan motivasi masingmasing. Praktik hibridisasi ini sangat terlihat di Korea Selatan khusunya pada konten drama bersamaan dengan menjamurnya pengaruh Western Media Mainstream dan mesin globalisasi seperti internet, pemasaran global, program televisi satelit dan kabel. Fenomena transmisi informasi global yang dilakukan melalui periklanan dan berita tampak menguntungkan negara maju dimana sektor industri dan ekonomi mengalami peningkatan progresif.

Strategi media Korea Selatan khususnya drama tampak dilakukan dengan mengadaptasi Western ethos dan Japanese spirit. Korea Selatan mengadopsi slogan Learning from Hollywood dari Amerika, sementara konsep dan spirit diadopsi dari Jepang sebagai strategi dalam merangkul segmentasi audience Asia sekaligus upaya menjunjung tinggi budaya Asian taste melalui konsep drama trendy. Akibatnya, beberapa penelitian terdahulu tidak berhenti memperdebatkan authencity drama Korea di abad ke-21 ini. Seperti contohnya adalah drama The Penthouse yang tampak mencolok menggunakan hybrid-culture antara 
Amerika dan Korea Selatan. Unsur mise-enscene, khususnya kostum Alex tampak seperti American style. Setting interior dan kostum penghuni The Penthouse tampak menyerupai Prancis style lengkap dengan adaptasi gaya busana King Louis XIV yang pakai para The Penthouse saat merayakan kemenangan Jo Dan Tae. Apapun yang terkait dengan budaya Amerika, baik dalam film, drama, musik, dan style sangat menunjukkan bahwa Korea Selatan telah mengambil gebrakan adaptasi budaya karena persaingan ekonomi global. Hibridisasi adalah strategi mencolok yang dilakukan Korea Selatan di masa postmodern abad ke-21 ini. Hal ini dibuktikan dengan adaptasi multi culture dalam beberapa serial dramanya, seperti The Penthouse yang memuat budaya Prancis, Amerika, dan beberapa Western culture lainnya. Meskipun Korea Selatan mengklaim bahwa konten yang diaplikasikan dalam drama adalah murni dari identitas budaya Korea, namun, hibridisasi tampak menjadi strategi baru di era globalisasi saat ini.

Adaptasi budaya Amerika tampak membuahkan hasil pada drama Korea. Seiring dengan kemajuannya, Korean Wave telah menjadi budaya populer dimana dampaknya telah dirasakan di berbagai negara. Namun, bersamaan dengan kemajuannya, Korean Wave sebagai gelombang budaya baru telah menjadi oposisi negara Jepang. Korea Selatan melakukan aklimatisasi content dari sisi Asian taste dan konsep trendy drama yang menyebabkan adanya persaingan berkepanjangan antar negara. Korean Wave dianggap telah mengkaburkan produk budaya Jepang (Haq, 2016).

Bagi non-Korea Selatan, Korea Wave ini tidak hanya sebagai wisata budaya baru, namun juga sebagai "tsunami budaya". Hal ini muncul dari adanya anggapan dari massive Korean fandom bahwa budaya Korea yang digambarkan dalam drama Korea sangat youthfully dan romantis dengan plot yang tidak rumit. Gairah romantisme tanpa sesksualitas terbuka dan memiliki represi emosi yang halus. Kesan Asian taste ini sangat mengacu pada Japanese spirit yang awalnya dikenal dengan konsep trendy drama-nya. Saat ini Korea berhasil menggeser image Jepang sebagai negara yang produktif karena produk budaya populernya yang saat ini digunakan sebagai promosi budaya, peningkatan pertumbuhan ekonomi, politik, dan hubungan diplomatik di era globalisasi (Kaisii, 2017).

Istilah globalisasi sendiri diartikan sebagai sesuatu yang memiliki ciri khas sosial kontemporer dengan proses multi-dimensi. Multi-dimensi mengacu pada hubungan ganda dan bukan hanya hubungan tunggal. Globalisasi tumbuh dalam hubungan kompleks namun erat karena saling ketergantungan di tatanan netwok society. Hal ini menimbulkan konsekuensi terhadap pertumbuhan budaya hibrid. Dampak 
globalisasi yang terjadi di era ini adalah adanya fenomena Korean Wave atau gelombang Korea. Disebut gelombang Korea karena dunia saat ini tengah dihadapkan pada adanya produk Korea yang massive seperti drama, film, musik dan gaya yang sangat diminati kaum muda. Produk media tersebut merupakan hasil dari hibridisasi budaya yang memiliki dua unsur pembentuk yakni budaya lokal dan western ethos. Drama Korea dikemas dengan konsep hybrid culture agar layak "dijual" di pasar dan hiburan global tanpa kompromi dengan tergesernya budaya lokal, karena cenderung "mengencerkan" kekhasan tradisi Korea. Oleh karena itu, Korean Wave bukanlah mengacu pada originalitas tradisi Korea namun merupakan versi westernisasi dari kombinasi budaya kedua negara.

Drama Korea diterima di wilayah international karena beberapa faktor yaitu, transparasi budaya, keterbukaan dalam perbedaan budaya, dan hibridisasi (Akter, 2019.). Akter selanjutnya menjelaskan bahwa keterbukaan inilah yang membawa Korea Selatan mendapatkan kesempatan untuk "dipercaya" khalayak international karena dianggap mampu menerima "sesuatu yang baru" di luar karakteristik budaya mereka. Akter juga tampak mendeskripsikan bahwa fenomena seperti ini berpotensi untuk menimbulkan kesalahpahaman yang berkelanjutan karena western culture dianggap mengabsorpsi lokalitas. Westernisasi berpeluang menggeser nilai lokalitas negara. Namun di sisi lain westernisasi juga berpotensi mendongkrak kreativitas pribumi. Sebagaimana Jepang yang pernah mengusung tema wakon yosai yang berarti Japanese spirit yang dipadupadankan dengan Western teknologi.

Untuk mendukung globalisasi dan pertumbuhan indutri budaya Korea Selatan, sektor, non-pemerintahan, dan level instansi pemerintah turut berperan serta melalui beragam penelitian dan produk budaya. Penelitian tentang budaya Korea dan efek Korean wave (gelombang Korea) juga tampak bervariasi di berbagai negara. Negara-negara di Asia seperti Jepang, China, Indonesia, Malaysia, dan Taiwan tampak berkontribusi dalam upaya perkembangan pengetahuan dampak Hallyu. Meskipun penelitian tentang drama Korea sudah sangat mendominasi, namun sayangnya penelitian-penelitian terdahulu hanya cenderung menganalisis tentang Korean media consumer semata (Tjoe \& Kim, 2016). Selain itu, penelitian juga cenderung membahas hibridisasi budaya dari pendekatan kuantitatif (Gardner, 2019).

Penelitian ini mengkaji tentang hibridisasi budaya dan lavish production dalam drama Korea terbaru yang dipublikasikan kurun waktu dua tahun terakhir, yaitu The World of the Married 2020 dan Touch Your Heart 2019. 
Kedua drama tersebut memiliki karakteristik romantisme yang hampir sama meskipun sangat berbeda dari plot, penyajian konflik dan ending cerita.

Drama Korea umumnya memiliki jumlah episode yang tidak terlalu banyak sekitar 8 episode seperti drama The Witch's Diner tayang 2021. Selain itu, di tahun 2020 ada $M y$ Holo Love sebanyak 12 episode, Kingdom 6 episode, Love Alarm sebanyak 8 episode yang di tayangkan di Netflix, My First First Love terdiri dari 8 episode. Kelima drama tersebut mengusung tema cinta kecuali Kingdom yang bertemakan seorang putra mahkota dengan misi menyelidiki wabah misterius di negaranya. The World of the Married 2020 memiliki dan Touch Your Heart 2019 berjumlah 16 episode.

The World of the Married 2020 cenderung memiliki hibridisasi budaya dengan western culture karena drama tersebut diadaptasi dari serial televisi Amerika berjudul Doctor Foster. The World of the Married 2020 menggambarkan isu "romantisme" yang membuat penonton tergelitik karena konflik perselingkuhan hingga perceraian yang memicu adanya pemikiran ketidakadilan gender pada perempuan bercerai (Syahira \& Supratman, 2021). Touch Your Heart 2019 tampak berbeda dengan The World of the Married 2020. Touch Your Heart 2019 cenderung menggambarkan hibridisasi Asian taste mengenai estetika "berpacaran" yang tercermin melalui dinamika visual, transisi, editing, dan atmosphere yang epic. Kesan Asian taste dan estetika baru dalam "berpacaran" ala Korea tampak tersampaikan secara utuh kepada penonton melalui unsur naratif dan cinematic drama tersebut.

Penelitian ini bertujuan untuk menganalisis hibridisasi budaya Korea karena adanya perdebatan penelitian-penelitian sebelumnya terkait keaslian budaya populer Korea dalam drama. Drama Korea secara kontekstual sering diperdebatkan karena dampak Western culture yang pernah melanda Korea atas adanya adaptasi slogan learning from hollywood (Chuang \& Lee, 2013).

Fenomena di atas menjadi landasan dilakukannya penelitian ini. Penelitian ini dilakukan untuk mengetahui bagaimana kecenderungan hibridisasi budaya populer drama Korea The World of the Married 2020 dan Touch Your Heart 2019. The World of the Married merupakan drama dengan jumlah terbanyak di streaming online berjumlah 55\% penonton melalui aplikasi Viu di Asia sejak awal pemutaran (Viu Singapura, 2020). Drama ini mendapat penghargaan bergengsi di Korea dalam ajang BaekSang Arts Awards pada Juni 2020, sekaligus drama terpopuler tahun 2020 (Media Indonesia, 2020). Drama Touch Your Heart juga mendapatkan penghargaan bergengsi dari Korean Culture and Entertainment Awards 
ke-27 dengan kategori Excelence Award (KMCC, 2019).

Penelitian ini menggunakan pendekatan lavish production. Adapun kecenderungan tema dan kekuatan visual berkesan lavish (mewah) pada kedua drama tersebut digunakan untuk mengetahui bagaimana Korea menkonstruksi citra modern negaranya. Lavish production berhubungan dengan bagaimana narasi dan visual drama dikonstruksi secara mewah untuk mengetahui hibridisasi, pencampuran serta perpaduan elemen lokal dan internasional dalam konten drama Korea (Ganti, 2013). Secara kontekstual, kombinasi multi-culture tersebut dianggap sebagai bentuk komoditas budaya populer sekaligus sebuah "budaya baru" karena fenomena akulturasi diantara budaya lokal dan global.

Adapun data primer dalam penelitian ini diambil dari potongan scene drama The World of the Married 2020 dan Touch Your Heart 2019. Sejumlah empat potongan scene yang kaya akan kesan lavish (mewah) digunakan sebagai sampel penelitian. Scene tersebut kemudian dikaji dan dianalisis secara mendalam.

Lavish production merupakan "kebaruan" dari adanya persepktif teori visual dalam drama maupun film di negara Korea yang sangat melekat pada classy mise-en-scene-nya. Lavish menjadi bermakna "lebih" dan bukan hanya sekedar mise-en-scene karena adanya hybrid technology yang dikembangkan pada saat proses produksi. Pada drama Korea, Lavish production juga berakar dari diadaptasinya slogan Learning from Hollywood dengan cita rasa Asia (Iwabuchi, 2004). Sehingga, lavish (mewah) tidak hanya dilihat melalui aspek visual saja, namun merupakan sesuatu yang sangat komplek karena menggabungkan dimensi konstruksi modern "citra baru" Korea melalui visual drama sebagai influencer bagi industri-industri hiburan di Asia. Karena alasan fundamental tersebut, maka penelitian ini bermaksud untuk menguak gaya lavish production melalui aspek mise-enscene sebagai cara untuk "membaca" bagaimana properti, asesoris, kostum, dan unsur naratif dapat merepresentasikan dimensi fisiologis, sosiologis, dan psikologis karakter tokoh (Sintowoko \& Sugihartono, 2014). Unsur miseen-scene tersebut juga berpengaruh terhadap bagaimana lavish production berhubungan kuat dengan visual drama. Adapun alasannya karena visual mampu "merepresentasikan citra" budaya populer di Korea sebagai nation-branding (Huang, 2011). Selain data primer, penelitian ini menggunakan data sekunder berupa kajian mise-en-scene, branding dan beberapa kajian hibridisasi budaya untuk mendukung data data primer tersebut.

Berdasarkan pemaparan diatas, maka penelitian ini mencakup dua hal yang sangat penting. Pertama, penelitian ini merupakan 
novelty dari beberapa penelitian drama Korea terdahulu yang hanya cenderung fokus terhadap permasalahan distribusi drama (Putri dkk., 2019). Penelitian terdahulu juga cenderung menganalisi tentang nilai-nilai kearifan lokal (Hidayat dkk., 2019). Kemudian penelitian juga seringkali fokus terhadap physical attractiveness dan analisis budaya populer dalam kecantikan (Nuraryo, 2019). Selain itu, analisis mengenai drama Korea juga sering tampak pada analisis enjoyment (Ulusoy \& Lee, 2019). Kedua, karena adanya fenomena diperdebatkannya originalitas budaya drama Korea oleh beberapa penelitian terdahulu. Adapun rumusan masalah penelitian ini adalah bagaimana visual lavish production menggambarkan hibridisasi budaya Korea dalam drama The World of the Married 2020 dan Touch Your Heart 2019? Adapun tujuan penelitian ini adalah untuk mengetahui bentuk hibridisasi budaya dari kedua drama, The World of the Married 2020 dan Touch Your Heart 2019 melalui pendekatan teori visual lavish production.

\section{METODE PENELITIAN}

Penelitian ini dilakukan dari bulan Desember 2020 hingga Agustus 2021. Jenis penelitian ini adalah deskriptif kualitatif dengan objek penelitian berupa potongan scene drama The World of the Married 2020 dan Touch Your Heart 2019. Sejumlah empat potongan scene yang kaya akan kesan lavish (mewah) dikaji dan dianalisis secara mendalam. Penelitian ini menggunakan jenis penelitian kualitatif dengan analisis mendalam (Nugrahani \& Hum, 2014). Penelitian ini menggunakan pendekatan teori lavish production yang merupakan "teknik kebaruan" karena menggabungkan teori miseen-scene dan visual "citra modern" yang dikonstruksi oleh media Korea sebagai nationbranding (Ju \& Lee, 2015).

Penelitian ini juga menggunakan teori hibridisasi budaya. Teori hibridisasi budaya dari Bhabha menjelaskan adanya kemunculan budaya baru yang unique sekaligus merupakan hasil dari perkawinan antara unsur colonizer (penjajah) dan colonized (terjajah), dimana kehadirannya menguji legitimasi identitas budaya lokal yang sudah mengakar (Li, 2016). Bhabha juga menekankan bahwa hibridisasi dikonstruksi dalam istilah third space karena adanya cultural adoption yang berdampak pada munculnya pencampuran budaya. Oleh karena itu, hasilnya sulit diklaim sebagai budaya "murni”.

Penelitian ini juga menggunakan teori sinematografi (cinematography) yang sangat berhubungan dengan teknik pengambilan gambar film. Angle sinematografi mendiskripsikan komposisi tipe gambar yang "unik". Sinematografi memiliki definisi yang tajam terkait bagaimana seseorang "menulis" 
dengan media audio visual. Sinematografi adalah creative metaphysical space yang di dalamnya kaya akan makna saat "dibaca" atau direpresentasikan secara makna visual. Penggunaan lavish production pada setproperty dan mise-en-scene merupakan projek menulis text visual. Komposisi, pergerakan kamera, dan lighting sangat dipertimbangkan sebagai manifestasi serta ekspresi ide dalam cinema. Sinematografi drama Korea di era 20 -an tampak mempertimbangkan lavish production atau kemewahan yang muncul dalam narasi visualnya.

Adapun teknik pengumpulan data dalam penelitian ini yaitu observasi secara langsung pada scene dalam drama Korea, The World of the Married 2020 dan Touch Your Heart 2019. Scene yang dipilih adalah scene yang mengandung kesan lavish production (mewah). Scene terpilih kemudian disajikan dalam bentuk gambar dan dideskripsikan secara mendalam untuk menjawab bentuk hibridisasi budaya melalui pendekatan lavish production dalam unsur mise-en-scene (kostum, properti, cinematography, camera movement, dan segala sesuatu yang melekat pada karakter).

\section{HASIL DAN PEMBAHASAN}

Pada bab hasil dan pembahasan, penelitian ini mendeskripsikan tiga poin pembahasan utama, yaitu: (1) fase hallyu 1.0 hingga 4.0; (2) tendensi tema drama Korea terbaru pada tahun 2018-2020; (3) analisis hibridisasi budaya dari perspektif lavish production drama The World of the Married 2020 dan Touch Your Heart 2019. Poin pembahasan pertama menjelaskan bagaimana strategi industri hiburan Korea dari masa ke masa karena adanya tuntutan politik dan persaingan ekonomi global. Strategi mencolok terlihat dari berbagai upaya industri hiburan Korea yang mengadaptasi slogan Learning from Hollywood dan trendy drama (modernisasi, young generation dan romantisme) drama dari Jepang. Adaptasi slogan tersebut tampaknya masih menjadi memicu adanya perdebatan para peneliti terdahulu terkait originalitas budaya Korea hingga saat ini.

Pembahasan poin kedua adalah bagaimana kecenderungan drama terbaru Korea selama dua tahun terakhir ini, 2018-2020. Adapun trendy drama dengan ciri khas gelora young generation dan tema romantisme masih tampak mendominasi. Pembahasan poin ketiga adalah terkait kecenderungan bagaimana visual lavish production dan hibridisasi drama tersebut. Oleh sebab itu, lavish production pada empat scene drama The World of the Married 2020 dan Touch Your Heart 2019 dianalisi secara mendalam dan berurutan dengan pemaparan sebagai berikut.

Fase Hallyu. Secara historis, terdapat empat kategori mendasar pada strategi industri budaya Korea. Keempat kategori tersebut 
disebut sebagai fase Korean Wave atau hallyu.

Fase tersebut yakni fase hallyu 1.0, hallyu 2.0, hallyu 3.0, dan hallyu 4.0 (Bokrae, 2015). Tabel 1 menunjukkan masing-masing fase hallyu yang disinyalir sebagai mega projek industri hiburan Korea untuk mendukung persaingan ekonomi negara di ranah global.

Fase hallyu (dari 1.0 hingga 4.0) adalah strategi pengembangan tren budaya populer Korea secara global yang dirancang setiap sepuluh tahun sekali. Jika dilihat dari tabel 1, tradisi dan drama tampak mengawali perkembangan hallyu. Namun lambat laun, sesuatu yang berbau modernisasi tampak mendominasi setelah industri media Korea mengadopsi slogan "Learningfrom Hollywood". Sejak fase hallyu 2.0, implementasi slogan tersebut menjadi semakin nyata terbukti dengan didistribusikannya segala produk Korea khususnya drama dan musik melalui Social Networking Service (SNS). Distribusi tersebut secara berurutan dimulai dari masyarakat non-Korean (on-site performance), online (YouTube), SNS, hingga aplikasi streaming seperti Netflix dan Viu di era industri 4.0 ini. Fase 4.0 tersebut merupakan terobosan mega proyek hallyu (B-cultural capital) dimana internet menjadi kekuatan besar dalam upaya distribusi produk budaya populer Korea. Kedepannya, fase hallyu 4.0 akan menekankan pada dirancangnya aturan-aturan terikat tentang publikasi Korean stars untuk menghindari dari tujuan komersial bebas. Strategi diciptakannya undang-undang dan aturan copyright merupakan terobosan untuk melindungi plagiasi budaya popular Korea di masa mendatang.

Pembahasan selanjutnya adalah bagaimana tendensi tema drama Korea pada tahun

\section{Tabel 1 Fase Hallyu dan Distribusi Budaya Korea}

\begin{tabular}{|c|c|c|c|c|}
\hline \multicolumn{5}{|c|}{ Fase Hallyu } \\
\hline & Hallyu 1.0 & Hallyu 2.0 & Hallyu 3.0 & Hallyu 4.0 \\
\hline Waktu & $1995-2005$ & $2006-2015$ & 2016-now & Now-future \\
\hline Area & $\begin{array}{l}\text { Asia (China, } \\
\text { Taiwan, Jepang, } \\
\text { Indone-sia }\end{array}$ & $\begin{array}{l}\text { Asia, Amerika } \\
\text { Utara, dan Eropa }\end{array}$ & Worldwide & World-wide \\
\hline Target & $\begin{array}{c}\text { Drama \& Film } \\
\text { Korea }\end{array}$ & K-starts-oriented & Artis dan brand & $\begin{array}{c}\text { Budaya } \\
\text { popular Korea dan } \\
\text { hak cipta }\end{array}$ \\
\hline Dis-tribusi & $\begin{array}{c}\text { Masyara-kat non- } \\
\text { Korea }\end{array}$ & Online (YouTube) & $\begin{array}{l}\text { SNS (jenis media } \\
\text { sosial Korea, } \\
F B, I G, \text { Kakao dsb) }\end{array}$ & $\begin{array}{c}\text { Online } \\
\text { stream-ing \& New } \\
\text { hegemoni }\end{array}$ \\
\hline Media & $\begin{array}{l}\text { Video, CD, spot } \\
\text { broadcasting }\end{array}$ & $\begin{array}{c}\text { Internet, \& on-site } \\
\text { performance }\end{array}$ & Cross-media & \\
\hline Durasi & Bulanan & Tahunan & Decade & \\
\hline
\end{tabular}


2018-2020. Setelah melakukan pengamatan melalui online streaming, peneliti menemukan kecenderungan tema trendy drama (romantisme) yang tampak mendominasi dari keseluruhan genre drama Korea (lihat tabel 2).

Tabel 2 seolah menunjukkan bahwa trendy drama seperti tema romantisme merupakan tema favorit yang diusung oleh industri hiburan Korea sekaligus yang banyak digemari penonton. Romantisme drama Korea sangat erat kaitannya dengan "estetika olah rasa". Adegan cenderung menitikberatkan pada romantic eye-contact dan non-sex orientation dengan narasi yang cute sebagai representasi Asian taste. Penggabungan estetika olah rasa dalam berpacaran dengan mise-en-scene yang cinematic tampak menjadi

Tabel 2 Daftar Drama Korea Tahun 2018-2020

\begin{tabular}{|c|c|c|}
\hline Tahun & Tema & Drama \\
\hline 2018 & \multirow{2}{*}{ Romantisme } & $\begin{array}{l}\text { Radio Romance, My First Love, Grand Prince, Should We Kiss } \\
\text { First, My Husband Oh Jak Doo, That Man Oh Soo, Good Witch }\end{array}$ \\
\hline 2019 & & $\begin{array}{l}\text { Angel's Last Mission:Love, Romance is a Bonus Book, When the } \\
\text { Camellia Blooms, Be Melodramatic, Search:WWW }\end{array}$ \\
\hline 2020 & \multirow[t]{2}{*}{ Keluarga } & $\begin{array}{l}\text { It's Okay to not be okay, Star-Up, Crash Landing on You, Record } \\
\text { of Youth }\end{array}$ \\
\hline \multirow[t]{2}{*}{2018} & & $\begin{array}{l}\text { Misty, Not Played 2018, Queen of Mystery 2, Shall We Live } \\
\text { Together, Miracle that We Met }\end{array}$ \\
\hline & \multirow[t]{2}{*}{ Hukum } & Return, Yeonnam-dong 539, Mistress \\
\hline 2020 & & Stranger 2 \\
\hline 2018 & \multirow{2}{*}{ Feminisme } & Fighter Choi Kang-Soon, Let's Go, Ami \\
\hline 2020 & & The World of the Married \\
\hline \multirow{5}{*}{2019} & Horror & $\begin{array}{l}\text { Kingdom, Hotel Del Luna; gender: Rookie Historian Goo Hae } \\
\text { Ryung }\end{array}$ \\
\hline & \multirow[t]{2}{*}{ History } & $\begin{array}{l}\text { The Crowned Clown, Her Private Life, Extraordinary You, } \\
\text { Chocolate, Touch Your Heart }\end{array}$ \\
\hline & & The King:Eternal Monarch \\
\hline & Action & Vagabond \\
\hline & \multirow[t]{2}{*}{ Persahabatan } & My Country \\
\hline \multirow{3}{*}{2020} & & Hospital Playlist \\
\hline & Education & Eye Are Dazzling \\
\hline & Action detective & The Good Detective, Flower of Evil \\
\hline
\end{tabular}

Sumber: Olahan Data Penulis, 2020 
ciri khas drama Korea untuk menarik perhatian penonton Asia seperti China, Taiwan, Jepang, Malaysia, dan Indonesia.

Pembahasan poin selanjutnya fokus terhadap bagaimana hibridisasi budaya jika dilihat dari pendekatan lavis (mewah) pada drama The World of the Married 2020 dan Touch Your Heart 2019.

The World of the Married. Secara naratif, The World of the Married tampak memperdebatkan norma sosial yang konservatif mengenai perkawinan, hubungan secara sosial antara suami-istri, perselingkuhan, pengasuhan anak, dan bahkan soal hierarki di tempat kerja di Korea. Kekuatan feminisme dalam drama ini seolah dikonstruksi sebagai terobosan baru citra perempuan Korea yang bukan sebagai cerita cinderella complex lagi. Alur cerita drama The
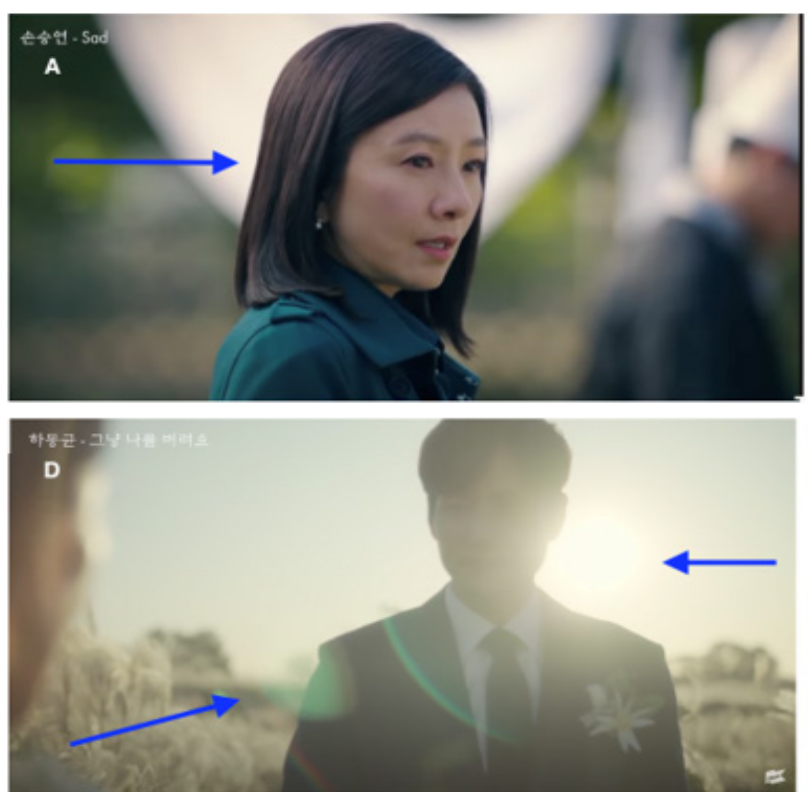

World of the Married tampak sebagai bagian dari postfeminism dimana visualisasi perempuan dan romantisme drama telah mengalami pergeseran. Pergeseran tersebut tampak pada bagaimana cerita perempuan sudah beralih dari dominasi cinderella complex menjadi feminism complex. Budaya patriaki sebelumnya juga kerap mucul dalam narasi perempuan, dimana perempuan identik dengan ketidakberdayaan dan objek seksual.

Secara visual, gambar 1 tampak menunjukkan kesan lavish atau kesan mewah. Hal ini dikarenakan adanya teknik Dept of Field (DOF). DOF fokus terhadap jarak antara objek terdekat dan terjauh dalam menentukan point of view visual agar tampak terlihat jelas (Pratiwi, 2017). Melalui teknik DOF, gambar 1 (A dan C) tampak mencerminkan
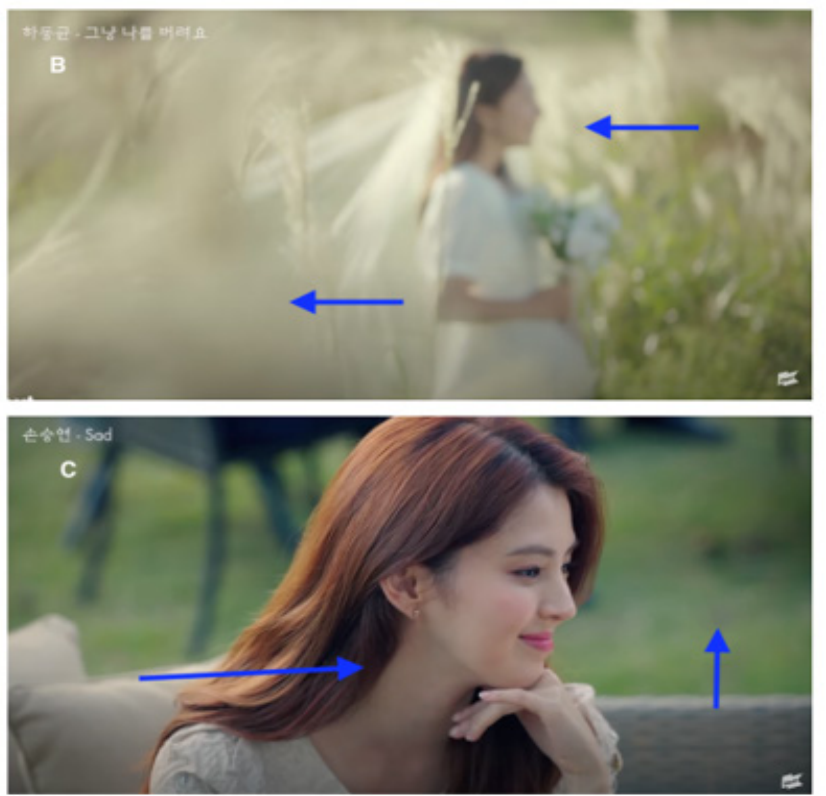

Sumber: The World of the Married 2020

Gambar 1 Potongan Scene Drama The World of the Married 2020 
detail ekspresi wajah karakter. Gambar 1 (A) dengan jelas menunjukkan ekspresi Dr. Ji Sun Woo yang tercengang saat mengetahui perselingkuhan suaminya. Emosi tersebut didukung dengan kostum berwarna hijau tosca yang seolah mengisyaratkan keteguhan hati seorang perempuan saat menahan amarah yang teramat dalam. Gambar 1 (B dan D) tampak dilakukan dengan teknik pengambilan gambar wedding cinematic style dengan kesan flare dari cahaya natural matahari. Visual seperti ini dapat menambah kesan lavish atau mewah. Teknik foreground dengan teknik blur juga tampak menunjukkan kedalaman value dengan kesan cinematic sekaligus sebagai mood cues (Bálint dkk., 2020).

Visual pada gambar 1 (C) juga merepresentasikan kesan lavish karena kesan standar Korean beauty yang identik dengan karakter artist, yaitu bertubuh langsing, bermata sipit dan berkulit putih. Smoot camera movement pada scene tersebut juga menunjukkan mood cues (Brown, 2013). Camera movement dalam cinematography tersebut tampak menggambarkan emosi, gesture dan ekspresi Ji Sun Woo yang tampak geram atas pengkhianatan yang ia terima dari suami dan lingkungan sekitarnya. Clasyy mise-enscene dalam scene ini tampak menggambarkan attitude dan kewibawaan Ji Sun Woo sebagai wanita cerdas, berpendidikan dan feminis.
Narasi dalam scene tampak kontradiktif namun tetap mampu menggambarkan mood drama itu sendiri. Kesan lavish juga tampak seringkali ditampilkan melalui gesture Ji Sun Woo yang menganut budaya modernisasi. Unsur sinematik dan naratif drama The World of the Married tampak terkesan epic dimana perubahan emosi karakternya dapat terlihat jelas melalui camera movement dan transisi gambar. Sehingga ekspresi, perasaan dan gesture masing-masing karakter terlihat jelas dan kontras yang dapat membuat penonton terbawa pada suasana yang komplek.

Kesimpulannya, citra perempuan Korea yang divisualkan dalam drama The World of the Married direpresentasikan secara lebih lavish atau mewah ketika dilihat dari kemandirian karakter Ji Sun Woo. Selain memprioritaskan attitude karakter dan penampilan, perempuan berpendidikan tinggi dengan karier yang mapan seolah juga menunjukkan evolusi dinamika isu gender dan feminisme di Korea Selatan seperti Gangnam accident pada tahun 2016, fenomena Megalia, dan gerakan Me Too. Ketiga isu tersebut cukup mendorong perubahan di dalam masyarakat Korea terkait pentingnya meningkatkan minat masyarakat (perempuan) untuk mempelajari feminism dan isu gender di universitas. Oleh karena itu, hibridisasi dan lavish production tidak hanya berlaku pada sesuatu yang tampak pada efek globalisasi saja, 
namun pemikiran modern ala Western style juga menjadi salah satu bentuk hibridisasi budaya (pemikiran) yang nyata di setiap adegan dan dialog drama The World of the Married 2020.

The World of the Married 2020 tampak memiliki kemiripan naratif denganv Doctor Foster (Lintang, 2020). Oleh sebab itu, originalitas cerita drama ini tampak diperdebatkan karena adanya rumor adaptasi plot dari serial televisi Amerika, Doctor Foster (lihat gambar 2). Karena kemiripan tersebut, penelitian ini menemukan bahwa hibridisasi budaya pasti terjadi dalam konten drama The World of the Married 2020 melalui visual dan narasinya.
Budaya popular Korea (K-pop) adalah bentuk liberalisme karena dianggap memiliki unsur Western culture dari sisi gesture, cara berpakaian dan gerakan tarian tubuh (Zahra, 2017). Gerakan tarian K-pop (2NE1) adalah contoh hibridisasi budaya. Elemen mise-enscene drama The World of the Married 2020 khususnya pada saat standing party juga bisa dikatakansebagai hibridisasibudaya.Hibridisasi budaya tersebut terlihat saat adegan standing party yang menyerupai Western style karena mencerminkan liberalisme. Selain itu, kostum pengantin (gambar 1 B) juga menggambarkan multi culture antara Korea dan Western style karena cenderung mencerminkan Western

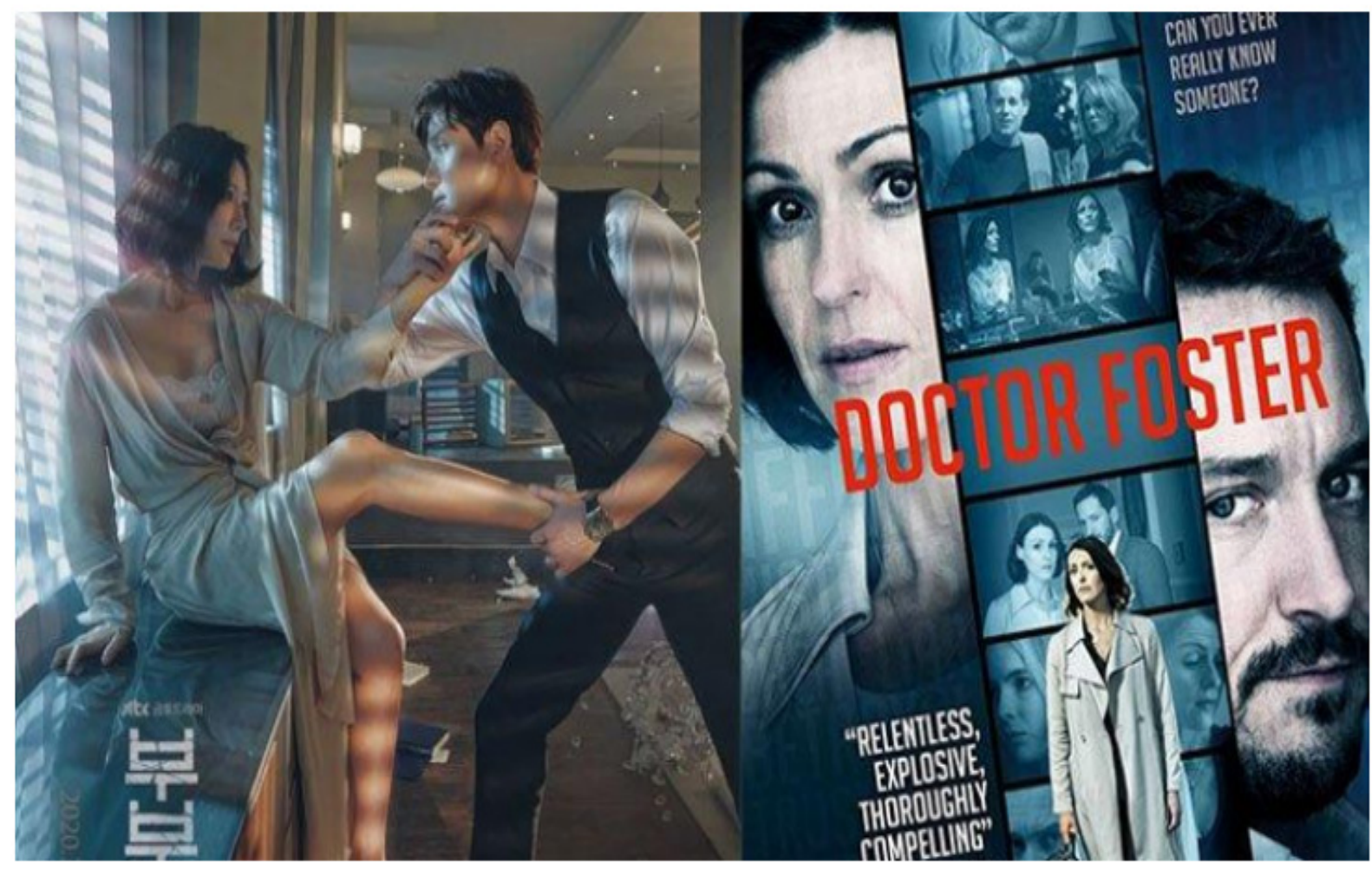

Sumber: JTBC \& BBC, 2020

Gambar 2 Poster drama The World of the Married \& Doctor Foster 
wedding style daripada Korean wedding style.

Penulis mengkritisi bahwa hibridisasi antara budaya Korea dan Amerika tidak terlepas dari bagaimana Korea mengadaptasi slogan Amerika, yaitu "Learning from Hollywood" sebagai strategi percepatan bisnis budaya populer melalui media. Learning from Hollywood mencakup berbagai elemen mise-enscene termasuk bagaimana adaptasi penggunaan kecanggihan teknologi, cinematography, distribusi, birokrasi dan branding. Korea pada akhirnya direpresentasikan sebagai cerminan Western culture di Asia termasuk dalam standar kecantikan Barat (Elfving, 2021).

Narasi The World of the Married dianggap memiliki kepentingan politis nasional meskipun juga menunjukkan ketidakpercayaan diri Korea dalam menggunakan pure budaya tradisionalnya sebagai dominasi target produk market dalam ranah global. Sehingga, drama The World of the Married tampak tidak ada hubungannya dengan agenda murni feminism di Korea, melainkan murni soal pencitraan dalam struktur masyarakat modern yang kompetitif seperti di Korea Selatan.

Analisis selanjutnya adalah drama Touch Your Heart. Drama Touch Your Heart bertema romantisme. Romantisme merupakan konsep trendy drama yang diadaptasi Korea dari Jepang dengan young generation sebagai target segmentasi penontonnya (Shim, 2020). Trendy drama identik dengan konsep modern dan stylish yang masih diimplementasikan pada fase gelombang Korea 4.0 sebagai cerminan Asian taste.

Secara naratif, Touch Your Heart menceritakan tentang seorang artis yang jatuh cinta dengan pengacara. Drama ini kaya akan kesan lavish (mewah) yang tampak pada gesture dan pemikiran Asian taste bahwa romantisme tidak semata-mata mengacu pada sex-orientation. Drama Touch Your Heart 2019 setidaknya tidak memiliki banyak adegan vulgar ataupun over sexuality sebagaimana yang kerap kali terlihat dari Western culture (Cahyowati, 2013). Touch Your Heart 2019 tampak merepresentasikan "budaya Asia" yang cenderung menggunakan "olah rasa" sebagai pembeda antara karakterstik budaya Barat dan Timur.

Gambar 4 menunjukkan bagaimana lavish production diaplikasikan dalam drama ini. Adanya cinematic wedding style dengan efek visual flare dan dominasi DOF tampak menunjukkan kesan lavish (mewah). Kostum berupa gaun mini berkesan sexy, make-up classy, sunglasses, highheel, anting berlian, dan jaket bulu menggambarkan kesan mahal karakter Oh Yoon Seo. Kriteria lavish kostum tersebut sangat menunjukkan dimensi sosiologis Oh Yoon Seo sebagai artis dan orang berkelas. Kombinasi angel kamera dan transisi 
detail ekspresi melalui close-up pada gambar

4 (C, E, dan F) menunjukkan mood cues dan kedalaman rasa yang dihasilkan melalui gaya visual (Tarvainen dkk., 2015). Oleh sebab itu, citra negara Korea sebagai negara maju dengan kesan classy dan romantis seolah-olah secara

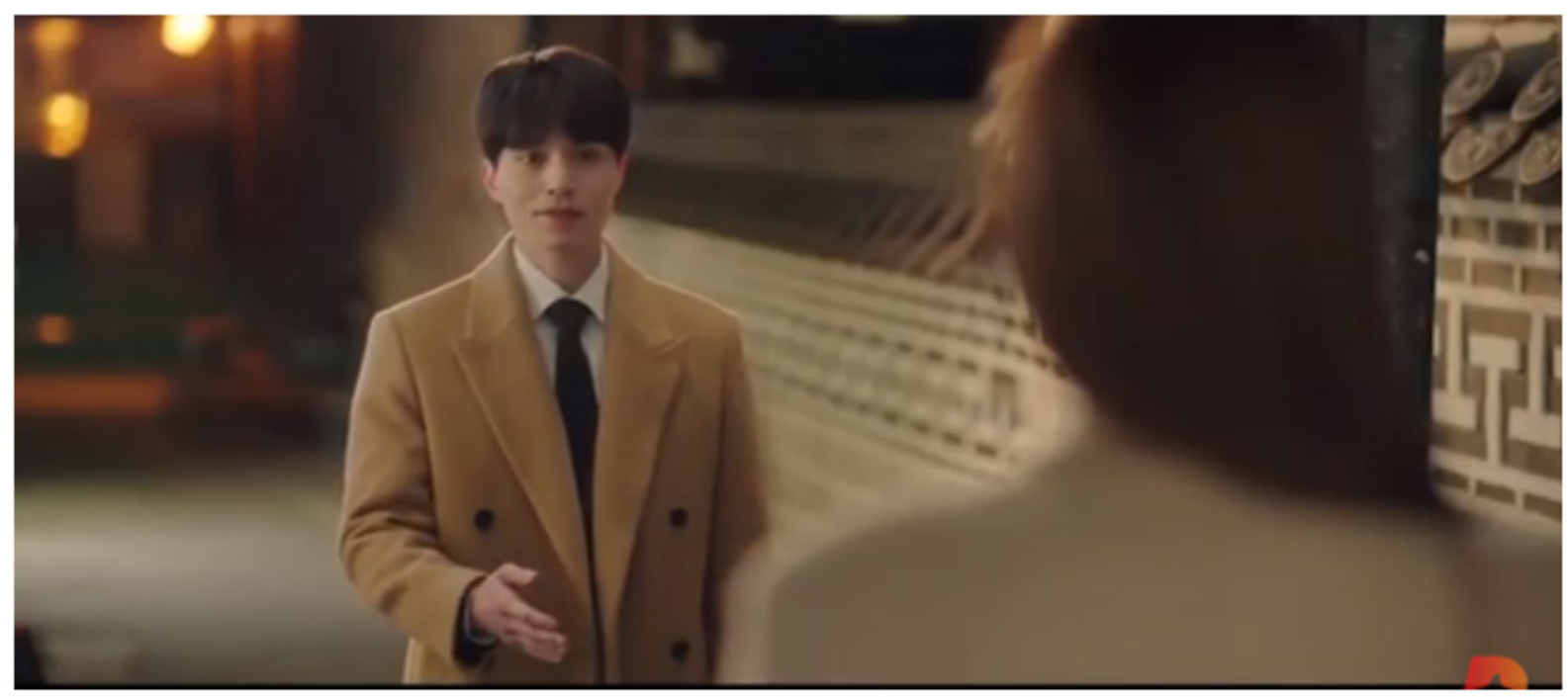

Sumber: Drama Touch Your Heart, 2019

Gambar 3 Episode 1 Cuplikan Drama Touch Your Heart
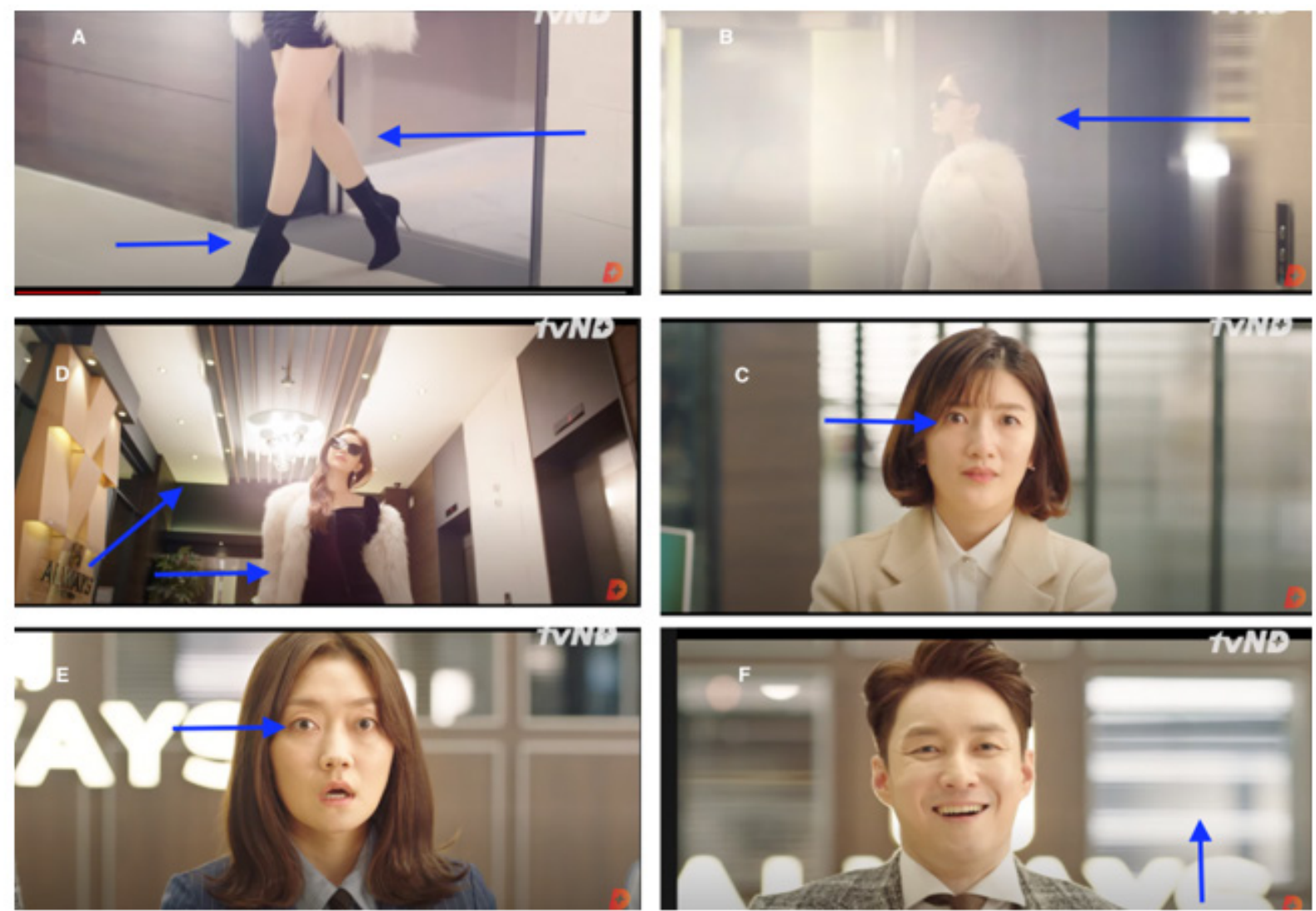

Sumber: Drama Touch Your Heart, 2019

Gambar 4 Lavish Production dalam Drama Touch Your Heart 
langsung ditunjukkan melalui visual tersebut.

Smoot camera movement, aspek mise-enscene, kostum dan set interior design (gambar 4) menambah kesan classy dan elegan dalam visual drama tersebut.

Konstruksibudayamodernyang divisualkan dalam drama seolah merepresentasikan adanya hibridisasi budaya (Korea vs. Western style) dimana percampuran ini mendorong perspesi masyarakat global secara massive terhadap citra modernisasi di Korea. Budaya populer dalam drama Korea merupakan kolaborasi antara budaya asli Korea dan multi nasional. Percampuran tersebut pada akhirnya menimbulkan konsekuensi terkikisnya budaya asli Korea. Korea Selatan mengadaptasi Amerika dari segi politik, ekonomi, dan sistem industri budaya sehingga memiliki kesamaan yang bisa mendorong munculnya pengaburan budaya otentik dan memicu budaya komersial (Larasati, 2018).

Pengaburan budaya otentik tercermin melalui gambar 4 (A) dimana mise-en-scene seperti setting, kostum, properti, makeup, dan penampilan karakter tampak masih menampilkan kesan lebih dinamis dengan mengikuti Western Style. Budaya populer Korea tampak mendominasi di Indonesia sejak awal tahun 2000-an (Jeong dkk., 2017). Budaya populer Korea digunakan sebagai alat politis semata. Hibridisasi dalam konten drama Korea juga masih diperdebatkan karena kurangnya unsur "Koreanness" dalam drama Korea.

Kesimpulan pemaparan dari tiga poin mendasar dalam pembahasan ini adalah bahwa masih terdapat hibridisasi dalam konten drama Korea dimana originalitas budaya lokal Korea masih dipertanyakan. Budaya populer telah menggeser budaya lokal Korea karena adanya komoditas. Komoditas yang sangat mencolok terlihat pada dieksploitasinya tubuh perempuan (long leg) sebagaimana yang terlihat dalam gambar 4 (A). Pakaian terbuka dan long leg menjadi indikator physical attractiveness di Korea sekaligus terciptanya enjoyment bagi media user terkait budaya Korea (Sintowoko dkk., 2020). Oleh sebab itu, budaya populer dalam drama The World of the Married 2020 dan Touch Your Heart 2019 menunjukkan kesan hibridisasi antara budaya Korea dan Amerika. Lokalitas budaya Korea tampak kurang mendominasi karena terkikis oleh Western media mainstream dan Western culture. Romantisme pada akhirnya tampak konservatif karena digunakan sebagai bentuk identitas budaya. Hibridisasi pada akhirnya juga hanya digunakan untuk menunjang kekuatan diplomasi dan ekonomi Korea (Rachmawati, 2019). Hal ini dikarenakan Korea merupakan negara yang memiliki tingkat persaingan dan kompetisi tinggi dimana tubuh perempuan kerap dijadikan komoditas kapitalisme (Kim dkk., 2020). 


\section{SIMPULAN}

Kesan lavish production pada drama The World of the Married 2020 dan Touch Your Heart 2019 dapat dilihat dari aspek ratio widescreen cinema standar. Kesan lavish production drama Korea juga dapat dilihat dari classy mise-enscene dengan beberapa teknik karakteristik wedding cinematic style seperti implementasi teknik flare, foreground, Deep of Field (DOF), dan blur

Teknik flare dibuat dengan cara memanfaatkan cahaya natural matahari ataupun lighting. Teknik ini juga tampak didominasi dengan pemanfaatan nature seperti ilalang sebagai mood cues agar kesan visual tampak lebih cinematic dan classy. Ciri teknik visual seperti ini merupakan bentuk dari kebaruan standar produksi drama Korea. Classy miseen-scene dengan penggabungan karakteristik wedding cinematic style dan widescreen cinema standar menjadi salah satu hal tercapainya lavish production. Lavish production pada akhirnya menjadi terobosan baru bagi strategi indutri drama Korea untuk menciptakan kesan mewah nan berkelas pada visualnya.

Hibridisasi budaya juga tampak pada kedua konten drama tersebut seperti yang tercermin pada adegan standing party. Standing party tampak menyerupai Western style karena mencerminkan liberalisme. Kostum dan gesture karakter juga menggambarkan adanya eksploitasi tubuh perempuan karena berorientasi pada budaya komersial. Konsep hibridisasi baru dalam gerakan feminism menjadi temuan untuk menciptakan kesan berkelas pada unsur narasi drama. Feminism menyangkut tentang revolusi mental, modernisasi dan feminisme Barat yang sudah merambah di Asia.

Hibridisasi terjadi karena adanya adaptasi slogan "Learning from Hollywood" dari Amerika dan konsep "drama trendy" dari Jepang. Adaptasi tersebut menghasilkan gerakan budaya Korea agar terlihat lebih dinamis. Trendy drama yang tercermin dalam drama Korea dahulu diadaptasi dari Jepang. Mise-en-scene dan gesture karakter tampak menggambarkan perkawinan hybrid culture dari multi-nation. Oleh sebab itu, hibridisasi akan semakin berkembang kedepannya karena perkembangan teknologi 4.0. Hibridisasi pada akhirnya bukanlah sesuatu yang perlu diperdebatkan karena merepresentasikan "cita rasa"dan "estetika" postmodernism. Perjumpaan yang menghasilkan karya hybrid tampak "wajar" dan sah-sah saja. Bahkan juga terjadi perselingkuhan antar estetika seni tradisi karena adanya perubahan pada tatanan baru third space cultures yang sangat kuat berhubungan dengan colliding cultures (budaya yang bertabrakan). Konsekuensi third space cultures ini adalah memunculkan sesuatu terkesan in-between 
space yang sulit dikenali, dinegosiasi makna dan representasi originalitasnya. Creator produk media harus mampu memilih dan bahkan harus mampu menyikapi itu. Mereka harus mampu memetakan sekaligus bertanggung jawab memperjuangkan wadah ekspresi berkarya seni dalam drama, atau menghasilkan karya drama yang adaptif sesuai dengan kelenturan dan agenda masing-masing. Budaya populer dalam hibridisasi memiliki keuntungan mudah "diterima" khalayak global dengan orientasi laku dan diminati tanpa banyak pertimbangan estetika. Sehingga, dalam hibridisasi originalitas budaya populer dianggap kurang begitu penting.

Sebagai saran, penelitian selanjutnya disarankan untuk menganalisis bagaimana visual hibridisasi budaya populer Korea secara lebih detail. Hibridisasi bisa dianalisis dari selain produk drama dengan pendekatan teori dan jenis penelitian yang berbeda untuk menemukan secara lebih jelas bagaimana hibridisasi akan berkembang menjadi sebuah "budaya baru" di era mendatang.

\section{DAFTAR PUSTAKA}

Akter, S.S. (2019.). Emergence of the "Korean Wave" and Its Influence on Bangladesh. Beppu Japan. https://ritsumei.repo.nii. ac.jp/?action=repository_action_common_ download\&item_id=11999\&item no $=1 \&$ attribute_id $=20 \&$ file_no $=1$. Doctoral dissertation, Ritsumeikan Asia Pacific University.
Bálint,K.E., Blessing, J.N., \& Rooney, B. (2020). Shot scale matters: The effect of close-up frequency on mental state attribution in film viewers. Poetics, 83, 101480. https:// doi.org/10.1016/j.poetic.2020.101480.

Bokrae, K. (2015). Past, present and future of Hallyu (Korean Wave). American International Journal of Contemporary Research, 5(5), 154-160. https://www. aijcrnet.com/journals/Vol_5_No_5 October_2015/19.pdf.

Brown, B. (2013). Camera movement. In Cinematography: Theory and Practice. A Focal Press Book, (pp. 223-240). https://books.google.co.id/books? hl=e $\mathrm{n} \& 1 \mathrm{r}=\& \mathrm{id}=\mathrm{GiQ}$ IDwAAQBAJ\&oi=fnd $\& p g=P P 1 \& d q=$ Camera + movement. $+\mathrm{I}$ $\mathrm{n}+$ Cinematography:+Theory+and + Pra ctice \& ots $=\mathrm{Oxp} 7-\mathrm{qvg} 35 \& \operatorname{sig}=\mathrm{h} 3 \mathrm{vMkH}$ XSCDGHveyr8HXLFzyoOpc\&redir e sc $=y \# v=$ onepage $\& \mathrm{q}=$ Camera $\% 20$ movement.\%20In\%20Cinematogra.

Cahyowati, T.D. (2013). Simbolisasi Seksualitas Perempuan dalam Iklan "Segar Sari Susu Soda" Versi Julia Perez. Jurnal Ilmu Ekonomi dan Sosial, 343. http:// puslit.mercubuana.ac.id/wp-content/ uploads/2013/09/Publikasi_Jurnal-Jild-1 Nomor-3.pdf $\#$ page $=114$

Chuang, L.M \& Lee, H.E. (2013). Korean wave: Enjoyment factors of Korean dramas in the US. International Journal of Intercultural Relations, 37(5), 594-604. https://doi. org/10.1016/j.ijintrel.2013.07.003.

Elfving, H.J. (2021). Media, cosmetic surgery and aspirational beauty aesthetics of the ageing body in South Korea. Asian Studies Review, 45(2), 238-252. DOI: 10.1080/10357823.2020.1736513.

Ganti, T. (2013). Bollywood: A guidebook to popular Hindi cinema. London: Routledge. 
https://doi.org/10.4324/9780203834411.

Gardner, H. (2019). The Impact of AfricanAmerican Musicianship on South Korean Popular Music: Adoption, Appropriation, Hybridization, Integration, or Other? Doctoral dissertation, http://nrs.harvard. edu/urn-3:HUL.InstRepos:42004187.

Haq, R. (2016). Penolakan Publik Jepang Terhadap Produk Budaya Korea Selatan. Jurnal Analisis Hubungan Internasional, 5(2), 344. http://journal.unair.ac.id/ download-fullpapers-jahi57f51d0919full. pdf.

Hidayat, D., Rosidah, Z., Retnasary M., \& Suhadi M. (2019). Nilai-nilai kearifan lokal pada unsur naratif dan sinematik film Jelita Sejuba. ProTVF, 3(2), 113-125. https://doi. org/10.24198/ptvf.v3i2.21264.

Huang, S. (2011). Nation-branding and transnational consumption: Japan-mania and the Korean wave in Taiwan. Media, Culture \& Society, 33(1), 3-18. https://doi. org/10.1177\%2F0163443710379670.

Iwabuchi, K. (2004). Feeling Asian modernities: Transnational consumption of Japanese TV dramas (Vol. 1). Dalam K. Iwabuchi. Hong Kong: Hong Kong University Press. https://books.google.co.id/books?hl=en\& $\mathrm{lr}=\& \mathrm{id}=$ ba7UAQAAQBAJ\&oi=fnd\&pg= PR5\&dq=Feeling + Asian + modernities: + T ransnational + consumption + of + Japanese $+\mathrm{TV}+$ dramas $+($ Vol. +1$) \&$ ots $=$ F6-N9rYWUf\&sig=ankJtNs9tjSwyQth1Nik786 $\begin{array}{llllllllll}\mathrm{y} & \mathrm{t} & \mathrm{U} & \& & \mathrm{r} & \mathrm{e} & \mathrm{d} & \mathrm{i} & \mathrm{r} & \end{array}$ es c $=y \# v=$ onepage $\& \mathrm{q}=$ Feeling $\% 20$ Asian $\% 20 m$

Iyorza, S \& Ekwok, L. (2014). Global media and cultural hybridization in the $21 \mathrm{st}$ Century in Nigeria. Journal of Social Sciences (COES\&RJ-JSS), 3(3), 408-416. http://www.centreofexcellence.net/J/JSS/
JSS Mainpage.htm.

Jeong, J.S., Lee, S.H., Lee, S.G. (2017). Korean Wave When Indonesians Routinely Consume Korean Pop Culture: Revisiting Jakartan Fans of Korean Drama Dae Jang Geum. International Journal of Communication, 11, 20. https://ijoc.org/ index.php/ijoc/article/view/6302.

Ju, H \& Lee, S. (2015). The Korean Wave and Asian Americans: the ethnic meanings of transnational Korean pop culture in the USA. Continuum, 29(3), 323-338. https:// doi.org/10.1080/10304312.2014.986059.

Kaisii, A. (2017). Globalization, hybridization and cultural invasion: Korean wave in India's North East. Asian Communication Research, 14(1), 10-35. DOI: 10.20879/ acr.2017.14.1.10.

Kim, G.E., Jo, M.W., \& Shin, Y.W. (2020). Increased prevalence of depression in South Korea from 2002 to 2013. Scientific reports, 10(1), 1-9. https://www.nature. com/articles/s41598-020-74119-4.

KMCC. (2019, December 3 ). “191129 ...". Diambil kembali dari Korean Pop Culture YouTube Channel (dalam bahasa Korea): https://www.youtube.com/ watch? $=35 \mathrm{ZMpqL} 32 \mathrm{eQ}$

Larasati, D. (2018). Globalization on Culture and Identity: Pengaruh dan Eksistensi Hallyu (Korean-Wave) Versus Westernisasi di Indonesia. Jurnal Hubungan Internasional, 11(1), 109-120. http://dx.doi.org/10.20473/ jhi.v11i1.8749.

Lee, Y.L., Jung, M., Nathan, R.J., \& Chung, J.E. (2020). Cross-national study on the perception of the Korean wave and cultural hybridity in Indonesia and Malaysia using discourse on social media. Sustainability, 12(15), 6072. https://doi.org/10.3390/ su12156072. 
Li, J. (2016). A Cultural Hybridization Perspective: Emerging Academic Subculture among International Students from East Asia in U.S. Universal Journal of Educational Research, 4(9), 2219. DOI:10.13189/ujer.2016.040934.

Lintang. (2020, Mei 16). Adaptasi, Ini Perbedaan The World of the Married dan Doctor Foster. Diambil kembali dari Oke Celebrity: https://celebrity.okezone.com/ $\mathrm{read} / 2020 / 05 / 16 / 598 / 2214989 /$ adaptasiini-perbedaan-the-world-of-the-marrieddan-doctor-foster

Media Indonesia. (2020, Mei 17). 'The World of the Married' is the most-watched drama on Viu . Diambil kembali dari Media Indonesia. 24 April 2020: https:// mediaindonesia.com/hiburan/307152/ drakor-a-world-of-married-couple-palingbanyak-ditonton-di-viu

Nugrahani, F \& Hum, M. (2014). Metode penelitian kualitatif. Solo. : Cakra Books. http://digilibfkip.univetbantara.ac.id/ materi/Buku.pdf.

Nuraryo, I. (2019). Kultur pop dan diskursus ideologi kecantikan pada iklan di televisi. ProTVF, 3(2), 171-184. https://doi. org/10.24198/ptvf.v3i2.21488.

Pratiwi, J. (2017). Depth of Field: Sebuah Telaah Historis Ruang Ketajaman. IMAJI: Film, Fotografi, Televisi, \& Media Baru, 9(1), 30-36. https://www.academia. edu/download/57375439/Depth_of_ Field_-_Sebuah_Telaah_Historis_Ruang_ Ketajaman.pdf

Putri, I.P., Liany, F.D.P., Nuraeni, R. (2019). K-Drama dan penyebaran Korean wave di Indonesia. ProTVF, 3(1), 68-80. https://doi. org/10.24198/ptvf.v3i1.20940.

Rachmawati, I. (2019). Film Sebagai Diplomasi Budaya. Jurnal Studi Diplomasi Dan
Keamanan, 11(1). https://doi.org/10.31315/ jsdk.v11i1.2916.

Shim, D. (2020). Transnational Koreans in Asian Pop Culture in the Pre-Korean Wave Era. Asian Communication Research, 17(3), 55-83. DOI:10.20879/acr.2020.17.3.55.

Sintowoko, D.A.W., Lee, Y., Lee, H.E. (2020). Cross-Cultural Difference between Female Young Adults in Korea and Indonesia in Perceiving Hijabis in the Media. International Journal of Internet, Broadcasting and Communication, 12(3), 177-188. https://doi.org/10.7236/ IJIBC.2020.12.3.177.

Sintowoko, D.A.W \& Sugihartono, R. (2014). Kostum Dalam Membangun Karakter Tokoh Pada Film Soekarno. Capture: Jurnal Seni Media Rekam, 6(1). https://doi. org/10.33153/capture.v6i1.725.

Syahira, H \& Supratman, L.P. (2021). Representasi Ketidakadilan Gender Pada Perempuan Bercerai Dalam Drama Korea" the World Of The Married". eProceedings of Management, 8(3). https:// openlibrarypublications.telkomuniversity. ac.id/index.php/management/article/ view/15011.

Tarvainen, J., Westman, S., Oittinen, P. (2015). The way films feel: Aesthetic features and mood in film. Psychology of Aesthetics, Creativity, and the Arts, 9(3), 254. https:// doi.org/10.1037/a0039432.

Tjoe, F.Z \& Kim, K.T. (2016). The effect of Korean Wave on consumer's purchase intention of Korean cosmetic products in Indonesia. The Journal of Distribution Science, 14(9), 65-72. https://doi. org/10.15722/jds.14.9.201609.65.

Ulusoy, E \& Lee, H.E. (2019). Effect of Gender on Character Evaluation: Factors Affecting Enjoyment. International 
journal of advanced smart convergence, 8(1), 214-221. https://doi.org/10.7236/ IJASC.2019.8.1.214.

Viu Singapura. (2020, Maret 2). A World of Married Couple Trailer \#2. YouTube. Viu Singapore. Diambil kembali dari When your world comes crashing | A World of Married Couple Trailer \#2 | Now on Viu: https://www.youtube.com/ watch? $\mathrm{v}=\mathrm{MtiPX} 82 \mathrm{dkus}$

Zahra, R.U. (2017). Representasi UnsurUnsur Budaya Western Pada Korean
Wave (Studi Analisis Semiotika Pada Video Musik Youtube Girlband Korea 2NE1). Malang. https://scholar. google.com/scholar?hl=en\&as $\mathrm{sdt}=0 \% 2 \mathrm{C} 5 \& \mathrm{q}=$ Representasi + UnsurUnsur+Budaya + Western + Pada + Ko rean + Wave $+\% 28$ Studi + Analisis + S emiotika+Pada+Video+Musik+You tube + Girlband + Korea +2 NE1\%29+$\% \mathrm{C}+$ Universitas + Brawijaya $\% 29 \& b t n G=$ : (Doctoral dissertation, Universitas Brawijaya). 